http://ejournal.uhn.ac.id/index.php/opinion

\title{
PENEGAKAN HUKUM DI INDONESIA DALAM RANGKA TATA KELOLA PEMERINTAHAN YANG LEBIH BAIK MENUJU 100 TAHUN KEMERDEKAAN INDONESIA (2045)
}

\author{
Martono Anggusti', Yansen Anggusti ${ }^{2}$ \\ Program Studi Magister Hukum \\ Program Pascasarjana \\ Universitas HKBP Nommensen, Medan-Sumatera Utara-Indonesia \\ e-mail: martono.pang@gmail.com
}

\begin{abstract}
President of the Republic of Indonesia, Joko Widodo said that, based on a number of calculations, Indonesia would perch as one of the five countries with the strongest economy in the world in 2045, when it entered Indonesia 100 years with millennial generation at the peak age of 40-51 years, and this is a productive age. Indonesia has the potential to be shared. 263 million population, who live on more than 17,00o islands consisting of 34 provinces and 514 cities / districts. This community is plural and part of 714 tribes with 1,100 more local languages. Although the majority of the population adheres to Islam, there are many residents of other religions too. No less important to note, that the implementation of decentralization in Indonesia shows the fate and quality of 2/3 (two thirds) of the citizens' lives, in practice, is largely determined by local government performance of services, ranging from environmental sanitation issues, such as waste management, school quality and health services. Everything depends on the high-low of public services quality in the area. The economic development in Indonesia, especially the legal matters, there is something that needs to be considered, that the law in Indonesia more towards criminal sanctions against companies, thus carrying the image that, if you want to be an entrepreneur, be prepared to be in prison. And this give opportunities for the officials trap in the abusement of power. A series of datas, regional officials arrested, 24 governors and 115 regents / mayors by the Corruption Eradication Commission (KPK) in 2004-2019. The majority of cases are related to bribery and gratification.
\end{abstract}

Keywords: Zoning, Stakeholders, Good and Clean Governance, Morals, Four Pillars.

\begin{abstract}
Abstrak
Presiden Republik Indonesia, Joko Widodo mengatakan bahwa berdasarkan sejumlah perhitungan, Indonesia akan bertengger sebagai salah satu dari lima negara dengan ekonomi terkuat di dunia pada tahun 2045, ketika itu, Indonesia memasuki 100 tahun dengan generasi milenial pada puncak usia 40-51 tahun, dan ini merupakan usia produktif. Indonesia memiliki potensi untuk dibagi. Populasi 263 juta yang tinggal di lebih dari 17.000 pulau yang terdiri dari 34 provinsi dan 514 kota / kabupaten. Komunitas ini majemuk dan bagian dari 714 suku dengan 1.10o lebih banyak bahasa lokal. Meskipun mayoritas penduduk menganut Islam, ada juga banyak penduduk dari agama lain. Yang tidak kalah penting untuk diperhatikan adalah implementasi desentralisasi di Indonesia menunjukkan nasib dan kualitas 2/3 (dua pertiga) dari kehidupan warga, dalam praktiknya, sangat ditentukan oleh jasa kinerja pemerintah daerah, mulai dari masalah kebersihan lingkungan, seperti pengelolaan limbah, hingga kualitas sekolah dan layanan kesehatan. Semuanya tergantung pada kualitas tinggi-rendah dari layanan publik di daerah tersebut. Dalam perkembangan ekonomi di Indonesia, terutama
\end{abstract}


http://ejournal.uhn.ac.id/index.php/opinion

dalam masalah hukum, ada sesuatu yang perlu dipertimbangkan, di mana hukum di Indonesia saat ini lebih mengarah pada sanksi pidana terhadap perusahaan, sehingga membawa image bahwa jika Anda ingin menjadi pengusaha Anda harus siap pergi ke penjara. Dan ini juga membuka peluang bagi pejabat negara untuk menyalahgunakan wewenang. Serangkaian data kepala daerah yang ditangkap, 24 gubernur dan 115 Bupati/Walikota oleh Komisi Pemberantasan Korupsi (KPK) pada 2004-2019. Mayoritas kasus terkait suap dan gratifikasi.

Kata kunci: Zonasi, Pemangku Kepentingan, Pemerintahan yang Baik dan Bersih, Moral, Empat Pilar.

\section{A. Pendahuluan}

Tujuan Negara Indonesia tercantum dalam Pembukaan Undang-Undang Dasar Negara Republik Indonesia Tahun 1945, paragraf keempat yang berbunyi, "Kemudian daripada itu untuk membentuk suatu Pemerintah Negara Indonesia yang melindungi segenap bangsa Indonesia dan seluruh tumpah darah Indonesia dan untuk memajukan kesejahteraan umum, mencerdaskan kehidupan bangsa, dan ikut melaksanakan ketertiban dunia yang berdasarkan kemerdekaan, perdamaian abadi dan keadilan sosial, maka disusunlah Kemerdekaan Kebangsaan Indonesia itu dalam suatu Undang Undang Dasar Negara Indonesia, yang terbentuk dalam suatu susunan Negara Republik Indonesia yang berkedaulatan rakyat dengan berdasarkan kepada Ketuhanan Yang Maha Esa, Kemanusiaan yang adil dan beradab, Persatuan Indonesia dan Kerakyatan yang dipimpin oleh hikmat kebijaksanaan dalam Permusyawatan/Perwakilan, serta dengan mewujudkan suatu Keadilan Sosial bagi seluruh rakyat Indonesia."

Sesuai dengan isi Pembukaan ayat empat UUD 1945, Negara Indonesia tidak berdiri sendiri dalam pembangunan negara Indonesia tetapi juga berkembang dengan mempertimbangkan kepentingan negara-negara lain di dunia, sehingga program Internasional juga harus dipertimbangkan dalam menjalankan administrasi di Indonesia. Implementasi dari tujuan pembangunan Milenium Development Goals (MDGs) masih jauh dari harapan dan komitmen 147 kepala negara dan tujuan negara Indonesia dalam target pencapaian pada tahun 2015. Selanjutnya Persatuan Bangsa Bangsa (PBB) telah menetapkan 17 tujuan SDGs sejak 21 Oktober 2015, antara lain: (1) Mengakhiri dalam segala bentuk dimanapun; (2) Mengakhiri kelaparan, mencapai ketahanan pangan dan nutrisi yang lebih baik dan mendukung pertanian berkelanjutan; (3) Memastikan kehidupan yang sehat dan mendukung kesejahteraan bagi semua untuk semua usia; (4) Memastikan pendidikan yang inklusif dan berkualitas setara, juga mendukung kesempatan belajar seumur hidup bagi semua, dan; (5) Mencapai kesetaraan gender dan memberdayakan semua poerempuan dan anak perempuan; (6) Memastikan ketersediaan dan manajemen air bersih yang berkelanjutan dan sanitasi bagi semua; (7) Memastikan akses terhadap energi dan terjangkau, dapat diandalkan, berkelanjutan dan modern bagi semua, (8) Mendukung pertumbuhan ekonomi yang inklusif dan berkelanjutan, tenaga kerja pemnuh dan produktif dan pekerjaan yang layak bagi semua, (9) Membangun infrastruktur yang tangguh, mendukung industralisasi yang inklusif dan berkelanjutan dan membantu perkembangan inovasi, (10) Mengurangi ketimpangan didalam dan antar negara, (11) Membangun kota dan pemukiman yang inklusif, aman, tangguh dan berkelanjutan, (12) Memastikan pola konsumsi dan produksi yang berkelanjutan, (13) Mengambil aksi segera untuk memerangi perubahan iklim dan dampaknya, (14) Mengkonversi dan memanfaatkan secra berkelanjutan sumber daya laut, samudera dan maritime untuk pembangunan berkelan jutan, (15) Melindungi, memulihkan dan mendukung penggunaan yang berkelanjutan, memernagi desetifikasi (penggurunan), dan menghambat dan membalikkan degradasi tanah 
Nommensen Journal of Legal Opinion (NJLO)

Jurnal Magister Hukum Program Pascasarjana Universitas HKBP Nommensen

Volume or Nomor o1 Juli 2020 Halaman. 38-52

e-ISSN: 2723-164X p-ISSN: 2722-9858

http://ejournal.uhn.ac.id/index.php/opinion

dan menghambat hilangnya keanekaragaman hayati. (16) Mendukung masyarakat yang damai dan inklusif untuk pembangunan berkelanjutan, menyediakan akses terhadap keadilan bagi semua dan emmbangun institusi institusi yang efektif, akuntabel dan inklusif disemua level, (17) Menguatkan ukuran implementasi dan merevitalisasi kemitraan global untuk pembangunan yang berkelanjutan. Tujuan Pembangunan Berkelanjutan (TPB)/Sustainable Development Goals (SDGs) adalah pembangunan yang menjaga peningkatan kesejahteraan ekonomi masyarakat secara berkesinambungan, pembangunan yang menjaga keberlanjutan kehidupan sosial masyarakat, pembangunan yang menjaga kualitas lingkungan hidup serta pembangunan yang menjamin keadilan dan terlaksananya tata kelola yang mampu menjaga peningkatan kualitas hidup dari satu generasi ke generasi berikutnya.

Nawacita berasal dari bahasa Sanskerta, nawa (sembilan) dan cita (harapan, agenda, keinginan). Pada Pemilu Presiden 2014 yang lalu, Nawa Cita merupakan istilah visi-misi dari pasangan calon presiden/calon wakil presiden Joko Widodo/Jusuf Kalla yang berisi pemaparan agenda pemerintahan pasangan Joko Widodo/Jusuf Kalla. Dalam visi-misi tersebut dipaparkan sembilan (9) agenda pokok Pemerintahanya, yang terdiri dari: (1) Menghadirkan kembali negara untuk melindungi segenap bangsa dan memberikan rasa aman pada seluruh warga negara, melalui politik luar negeri bebas aktif, keamanan nasional yang terpercaya dan pembangunan pertahanan negara Tri Matra terpadu yang dilandasi kepentingan nasional dan memperkuat jati diri sebagai negara maritime; (2) Membuat pemerintah tidak absen dengan membangun tata kelola pemerintahan yang bersih, efektif, demokratis, dan terpercaya, dengan memberikan prioritas pada upaya memulihkan kepercayaan publik pada institusi-institusi demokrasi dengan melanjutkan konsolidasi demokrasi melalui reformasi sistem kepartaian, pemilu, dan lembaga perwakilan; (3) Membangun Indonesia dari pinggiran dengan memperkuat daerah-daerah dan desa dalam kerangka negara kesatuan; (4) Menolak negara lemah dengan melakukan reformasi sistem dan penegakan hukum yang bebas korupsi, bermartabat, dan terpercaya; (5) Meningkatkan kualitas hidup manusia Indonesia melalui peningkatan kualitas pendidikan dan pelatihan dengan program "Indonesia Pintar", serta peningkatan kesejahteraan masyarakat dengan program "Indonesia Kerja" dan "Indonesia Sejahtera” dengan mendorong land reform dan program kepemilikan tanah seluas 9 hektar, program rumah kampung deret atau rumah susun murah yang disubsidi serta jaminan sosial untuk rakyat di tahun 2019; (6) Meningkatkan produktivitas rakyat dan daya saing di pasar internasional sehingga bangsa Indonesia bisa maju dan bangkit bersama bangsa-bangsa Asia lainnya; (7) Mewujudkan kemandirian ekonomi dengan menggerakkan sektor-sektor strategis ekonomi domestic; (8) Melakukan revolusi karakter bangsa melalui kebijakan penataan kembali kurikulum pendidikan nasional dengan mengedepankan aspek pendidikan kewarganegaraan, yang menempatkan secara proporsional aspek pendidikan, seperti pengajaran sejarah pembentukan bangsa, nilai-nilai patriotisme dan cinta Tanah Air, semangat bela negara dan budi pekerti di dalam kurikulum pendidikan Indonesia; (9) Memperteguh kebhinnekaan dan memperkuat restorasi sosial Indonesia melalui kebijakan memperkuat pendidikan kebhinnekaan dan menciptakan ruang-ruang dialog antar warga.

Pembangunan pada hakikatnya diupayakan dalam rangka untuk mencapai suatu kesejahteraan rakyat sesuai dengan yang diamanatkan dalam Pembukaan UUD 1945, dimana tujuan dari berdirinya Negara Republik Indonesia adalah mewujudkan sebuah kesejahteraan bangsa. Implementasi dari Pembukaan UUD 1945 tersebut kemudian diimplementasikan dalam Pasal 33 ayat (3) UUD 1945, dimana dalam pasal tersebut dinyatakan bahwa bumi, air, dan kekayaan alam yang terkandung di dalamnya dikuasai Negara dan dipergunakan sebesarbesarnya kemakmuran rakyat. Pertanyaannya adalah bagaimana hasil Das Sollen dan Das Sein. 
Nommensen Journal of Legal Opinion (NJLO)

Jurnal Magister Hukum Program Pascasarjana Universitas HKBP Nommensen

Volume or Nomor o1 Juli 2020 Halaman. 38-52

e-ISSN: 2723-164X p-ISSN: 2722-9858

http://ejournal.uhn.ac.id/index.php/opinion

Proses pembangunan sebuah bangsa pada umumnya akan melalui beberapa tahapan, yaitu: tahap unifikasi, yaitu pada tahap ini sebuah bangsa dihadapkan pada masalah integrasi nasional dari beberapa kekuatan nasional yang ada. Tahap selanjutnya adalah tahap industrialisasi dimana pada tahap ini sebuah Negara berupaya untuk menerapkan konsep industrialisasi untuk mengejar laju pembangunan. Pada tahap ketiga sebuah Negara akan mencapai tahap social welfare, yaitu pada saat ini tujuan pembangunan Negara diharapkan telah tercapai, yaitu menciptakan kesejahteraan rakyat. Konsep pertumbuhan ekonomi pada dasarnya mengacu pada konsep pertumbuhan ekonomi yang diterapkan formulasinya oleh Max Weber. Formula yang dikembangkan oleh Max Weber membutuhkan hukum sebagai salah satu landasan pembangunan industrialisasi di Eropa. Menurutnya peranan hukum dalam pembangunan setidaknya harus mampu menciptakan lima kondisi yaitu Stability, Predictibality, Fairness, Education, dan The special development abilities of the lawyers.

Kondisi konvergensi globalisasi, revolusi industri 4.0, bencana nasional (covid-19), bonus demografi dan masalah diversitas perundang-undangan, peraturan-peratruran yang diterbitkan karena kepentingan politik kembali mengingatkan kita pada kata-kata pidato presiden pertama Indonesia, Bapak Soekarno, yang menyatakan bahwa "Beri Aku 1000 orang Tua, Niscaya Akan Kucabut Semeru Dari Akarnya, Beri Aku 10 Pemuda, Niscaya Akan Kuguncang Dunia." ini mengartikan bahwa, kita tidak perlu menunggu bonus demografi untuk bisa memberikan kehormatan yang layak bagi bangsa dan negaranya. Bung Karno hanya membutuhkan pemuda-pemudi unggul yang memiliki kualitas dan visi yang besar dalam menatap dunia. Tetapi perlu menjadi pertanyaan mendasar mengenai kondisi mental generasi muda bangsa Indonesia saat ini. "Perjuanganku lebih mudah karena melawan penjajah. Tapi perjuangan kalian akan lebih berat, karena melawan saudara sendiri.” Bangsa Indonesia sudah jauh dari prinsip kekeluargaan, kebersamaan dan gotong royong dan lebih senang menganut asas liberalisasi, individualisme dan kapitalisme yang diadop dari dunia barat, sehingga gampang terjadi perpecahan-perpecahan yang sering muncul dengan sikap demo-demo. Apabila tidak kita pegang kokoh dan dipertahankan secara bersama prinsip Empat Pilar berbangsa dan bernegara (Pancasila, UUD 1945, Negara Kesatuan Republik Indonesia (NKRI) dan Bhinneka Tunggal Ika). Kondisi negara dan bangsa Indonesia dalam ujian besar.

Kondisi politik yang ada di Indonesia saat ini mengalami tingkat 'buruk'. Keterpurukan ini disebabkan perpolitikan Indonesia yang tidak sehat. Banyak politisi di negara ini yang terlibat kasus korupsi. Mereka lebih mementingkan kepentingan pribadi dan lupa akan tugasnya sebagai pejuang rakyat. Indonesia tengah mengalami masalah yang cukup serius. Hilangnya nilai pancasila dalam kehidupan bermasyarakat dan dunia perpolitikan telah menimbulkan masalah yang sampai sekarang belum terpecahkan. Budaya malu dalam korupsi tidak berlaku, terbukti dari masih banyaknya para tokoh atau pejabat publik yang tetap terpilih kembali meskipun sebelumnya dia pernah dicap sebagai "koruptor".

Sejak kasus Covid-19 meningkat di Indonesia, berbagai permasalahan sosial dan ekonomi muncul di tengah masyarakat. Tak dapat dipungkiri jika Covid-19 telah hampir melumpuhkan kondisi sosial ekonomi masyarakat Indonesia, khususnya di beberapa daerah dengan tingkat penyebaran tertinggi. Perubahan sosial atau perkembangan sosial budaya di Indonesia dapat dilihat telah mengikuti perubahan zaman yang sedang berkembang secara global. Dimana banyak kebudayaan-kebudayaan asing yang mulai dianut oleh masyarakat Indonesia, pola pemikiran yang lebih condong ke barat, hingga mungkin meninggalkan tradisi atau kebiasaan yang sebenarnya telah lama ada di masyarakat Indonesia itu sendiri. Salah satu penyebabnya adalah karena adanya zaman yang semakin berkembang dan teknologi yang semakin canggih yang mempermudah segala aspek kehidupan yang kemudian sangat berpengaruh terhadap kehidupan masyarakat Indonesia dalam bersosialisasi maupun berinteraksi. 
http://ejournal.uhn.ac.id/index.php/opinion

Berdasarkan data Worldometers, Indonesia saat ini memiliki jumlah penduduk sebanyak 269 juta jiwa atau 3,49\% dari total populasi dunia. Indonesia berada di peringkat keempat negara berpenduduk terbanyak di dunia setelah Tiongkok (1,42 miliar jiwa), India (1,37 miliar jiwa), dan Amerika Serikat (328 juta jiwa). Kawasan di Indonesia terbagi menjadi beberapa provinsi. Jumlah provinsi di Indonesia terbaru pada saat ini berjumlah 34 provinsi. Indonesia memiliki lebih dari 300 kelompok etnik atau suku bangsa, lebih tepatnya terdapat 1.340 suku bangsa di Tanah Air menurut sensus BPS tahun 2010. Suku Jawa adalah kelompok terbesar di Indonesia dengan jumlah yang mencapai $41 \%$ dari total populasi. Diprediksi Indonesia akan mengalami masa bonus demografi, yakni jumlah penduduk usia produktif (berusia 15-64 tahun) lebih besar dibandingkan penduduk usia tidak produktif (berusia di bawah 15 tahun dan di atas 64 tahun). Pada bonus demografi tersebut, penduduk usia produktif diprediksi mencapai 64 persen dari total jumlah penduduk yang diproyeksikan sebesar 297 juta jiwa. Bonus demografi adalah tantangan sekaligus kesempatan besar. Bagaimana bangsa ini mampu menghasilkan sumber daya manusia yang kreatif dan inovatif dan mampu menyediakan lapangan kerja.

\section{B. Metode Penelitian}

Menurut Soerjono Soekanto: "Penelitian adalah kegiatan ilmiah berdasarkan analisis dan konstruksi yang dilakukan secara sistematis, metodologis dan juga konsisten dan bertujuan untuk dapat mengungkap kebenaran adalah sebagai salah satu wujud keinginan manusia untuk dapat mengetahui tentang apa yang sedang dihadapi ”. Penelitian ini dilakukan agar pencapaian tujuan kesejahteraan dan perdamaian dapat terwujud sesegera mungkin di tanah air Indonesia, seperti yang dicita-citakan ketika negara Indonesia merdeka. Kemajemukan bangsa hidup bersama dalam keharmonisan dan berdampingan. Penelitian ini merupakan jenis penelitian lapangan dengan pendekatan kualitatif. Kirk dan Miller mendefinisikan penelitian kualitatif sebagai tradisi khusus dalam ilmu sosial yang secara fundamental bergantung pada pengamatan pada manusia baik di wilayahnya maupun dalam terminologinya. Dalam penelitian ini juga didukung oleh penelitian kepustakaan yaitu sumber data berupa buku atau literatur yang berhubungan dengan diskusi atau melalui sumber data di internet. Penelitian kualitatif adalah penelitian yang menghasilkan prosedur analitik yang tidak menggunakan prosedur analisis statistik atau metode kuantifikasi lainnya. Jelas bahwa gagasan ini kontras penelitian kualitatif dengan penelitian kuantitatif dengan menggarisbawahi bahwa setiap upaya kuantifikasi tidak boleh digunakan dalam penelitian kualitatif.

Studi makalah ini akan menggunakan teori utilitas "kebahagiaan terbesar untuk jumlah terbesar", dipelopori oleh Jeremy Bentham, didukung oleh R. Edward Freeman dalam teorinya, "Teori Stakeholder dari Modern Corporation", teori pemangku kepentingan didasarkan pada dua prinsip yang menyeimbangkan hak-hak pengadu kepada perusahaan dengan konsekuensi dari bentuk perusahaan. Yang Pertama, prinsip sekuritas perusahaan, menyatakan bahwa "Perusahaan dan para manajernya bertanggung jawab atas dampak tindakan mereka terhadap orang lain". Prinsip kedua, yaitu prinsip hak perusahaan, menyatakan bahwa "Perusahaan dan para manajernya tidak melanggar hak sah orang lain untuk menentukan masa depan mereka sendiri". Prinsip ini berasal dari teori Deontologis Immanuel Kant (1724-1804) berdasarkan prinsip penghormatan terhadap orang-orang bahwa orang harus diperlakukan sebagai tujuan dan tidak pernah hanya sebagai sarana. Menurut Kant tindakan itu baik, jika karena kewajiban (imperatif kategoris), yang mewajibkan adil, terlepas dari kondisi apa pun. Mengelola negara yang didukung oleh industri untuk meningkatkan standar hidup dan kesejahteraan rakyat sebagai pemangku kepentingan utama adalah tindakan yang benar dan merupakan kewajiban 
Nommensen Journal of Legal Opinion (NJLO)

Jurnal Magister Hukum Program Pascasarjana Universitas HKBP Nommensen

Volume or Nomor o1 Juli 2020 Halaman. 38-52

e-ISSN: 2723-164X p-ISSN: 2722-9858

http://ejournal.uhn.ac.id/index.php/opinion

negara dan juga sebagai bangsa. Dan jika konsep ini dikaitkan dengan keadilan, maka adalah adil bahwa manajemen dalam mengelola negara yang didukung oleh industri berkaitan dengan peningkatan standar hidup dan kesejahteraan rakyat juga disebut sebagai bangsa dan masyarakat sekitarnya sebagai pemangku kepentingan. John Rawls berpendapat bahwa situasi masyarakat harus sedemikian rupa sehingga keuntungan tertinggi yang dihasilkan mungkin untuk kelas-kelas kecil dan untuk semua orang diberi kesempatan yang sama dalam hidup mereka. Seperangkat kerangka teoritis seperti di atas dianggap relevan untuk digunakan sebagai pisau analis dalam penelitian makalah ini.

\section{Pembahasan}

Dewasa ini paradigma pengelolaan pemerintahan dalam rangka membentuk kenegaraan yang baik dan benar sudah masuk pada tahap pemerintahan yang baik atau akrab kita sebut dengan istilah good governance. Seiring dengan hal itu, ternyata paradigma pembangunan Indonesia secara nasional sebagai bagian dari warga global juga sudah mengalamai perubahan, yakninya pembangunan berkelanjutan (SDGs). Dengan demikian, dapat di garis bawahi bahwa dalam membentuk tata pemerintahan yang baik sejatinya harus terdiri dari tiga komponen, antara lain pemerintah, masyarakat, dan swasta. Salah satu pemicu terbentuknya good governance di Indonesia adalah semakin mencuatnya tuntutan masyarakat terhadap kualitas demokrasi, terancamnya hak asasi manusia, dan kurang efektifnya pemerintahan, sehingga masyarakat dengan kesadaran penuh meminta pemerintah untuk lebih bertanggungjawab dan adanya transparansi pejabat publik. Penyelenggaraan pemerintahan yang baik memiliki beberapa asas yang dimaktubkan dalam UU Nomor 28 Tahun 1999 tentang Penyelenggara Negara yang Bersih dan Bebas dari Korupsi, Kolusi dan Nepotisme pada pasal (3) antara lain: asas kepastian hukum, asas tertib penyelenggara Negara, asas kepentingan umum, asas keterbukaan, asas proporsionalitas, asas profesionalitas, dan asas akuntabilitas. Selain itu, Indonesia juga sedang diselimuti paradigma pembangunan berkesinambungan. Pelaksana SDGs di Indonesia mencakup dua hal. Pertama, komitmen Presiden Jokowi untuk secara langsung memimpin pelaksanaan Tujuan Pembangunan Berkelanjutan dengan menyiapkan Peraturan Presiden. Kedua adalah memastikan partisipasi publik. Organisasi masyarakat sipil, akademisi, pelaku bisnis, dan lembaga filantropi menjadi yang utama aktor dalam pelaksanaan SDG harus mematuhi prinsip tidak ada yang tertinggal, semuanya berjalan seiring.

Bonus demografis harus disertai dengan pertumbuhan Usaha Mikro Kecil Menengah (UMKM) nasional, tetapi pertumbuhan UMKM dibandingkan dengan negara-negara di Asia Tenggara (ASEAN), Singapura masih berada di garis depan dalam mencetak pengusaha yang mencapai $7 \%$ (dari populasi), Malaysia 5\%, Thailand 3\%, sedangkan Indonesia 1,65\%. Data dari Kementerian Koperasi dan UKM menunjukkan jumlah pengusaha di beberapa negara lain di dunia, termasuk Korea Selatan 4\%, Jepang 10\%, Cina 10\% dan Amerika Serikat 12\%. Selain rendahnya pertumbuhan UMKM nasional, iklim investasi di Indonesia cukup tidak menarik. Ini dibuktikan dengan minat investor untuk berinvestasi di Indonesia masih rendah dibandingkan dengan negara tetangga. Berdasarkan laporan Bank Dunia, 33 perusahaan Cina telah memutuskan untuk meninggalkan Amerika Serikat. Dari jumlah itu, 23 di antaranya memilih berinvestasi di Vietnam. Sisanya pergi ke Malaysia, Kamboja, dan Thailand. Pada 2017, 73 perusahaan Jepang pindah ke wilayah Asia Tenggara. Sebanyak 43 di antaranya memilih Vietnam, 11 perusahaan ke Thailand dan Filipina. Sedangkan Indonesia hanya 10 perusahaan dari Jepang.Tahun 2105-2019, jumlah penciptaan lapangan kerja baru telah mencapai 11.196.270. Selain itu, tingkat pengangguran terbuka di Indonesia saat ini berada pada 5,01 persen, yang merupakan tingkat pengangguran terendah dalam sejarah Indonesia. Terkait dengan Usaha Mikro, Kecil dan Menengah (UMKM), ada sekitar 58 juta usaha wiraswasta dan sekitar 1,65 
Nommensen Journal of Legal Opinion (NJLO)

Jurnal Magister Hukum Program Pascasarjana Universitas HKBP Nommensen

Volume o1 Nomor o1 Juli 2020 Halaman. 38-52 e-ISSN: 2723-164X p-ISSN: 2722-9858

http://ejournal.uhn.ac.id/index.php/opinion

persen dari populasi telah menjadi wirausahawan yang dulunya berasal dari usaha baru (pemula) dan mampu mengembangkan bisnis mereka. Peran strategis UMKM dalam struktur ekonomi Indonesia semakin jelas di mana 99,9 persen unit bisnis di Indonesia adalah UMKM. Salah satu arahan Presiden Joko Widodo dalam pidato pelantikan Presiden dan Wakil Presiden untuk periode 2020-2024, menyatakan keinginan Pemerintah untuk merealisasikan dua peraturan yang menjadi prioritas Pemerintah, yaitu Undang-Undang Hak Cipta Ketenagakerjaan dan UU Pemberdayaan UMKM. Ini dilakukan sebagai langkah bagi Indonesia untuk keluar dari jebakan pendapatan kelas menengah. Potensi bonus demografi di mana populasi usia produktif jauh lebih tinggi daripada usia tidak produktif, ini adalah tantangan besar serta peluang besar. Sayangnya akibat bencana nasional (covid-19) merusak rencana yang telah dalam proses. Dan gawatnya adalah sejak terjadinya bencana nasional (covid-19) UMKM juga tergeletak hancur.

Zonasi dikenal pula dengan istilah pengaturan zonasi dan peraturan zonasi dikenal dalam Undang-Undang No 26 Tahun 2007 Tentang Penataan Ruang (selanjutnya disebut sebagai UUPR) merupakan pedoman pengendalian pemanfaatan ruang. Peraturan Zonasi disusun berdasarkan rencana rinci tata ruang untuk setiap zona pemanfaatan ruang. peraturan zonasi ditetapkan dengan: Peraturan pemerintah untuk arahan peraturan sistem nasional; Peraturan daerah provinsi untuk arahan peraturan zonasi sistem provinsi; dan Peraturan daerah kabupaten/kota untuk peraturan zonasi. (bunyi pasal 35 dan 36 UUPR).

Peraturan zonasi merupakan ketentuan yang mengatur pemanfaatan ruang dan unsurunsur pengendalian yang disusun untuk setiap zona peruntukan sesuai dengan rencana rinci tata ruang. Menurut Pasal 1 angka 15 Peraturan Pemerintah Nomor 15 Tahun 2010 tentang Penyelenggaraan Penataan Ruang (selanjutnya disebut PP PPR) diatur bahwa pengaturan zonasi adalah ketentuan tentang persyaratan pemanfaatan ruang sektoral dan ketentuan persyaratan pemanfaatan ruang untuk setiap blok/zona peruntukan yang penetapan zonanya dalam rencana rinci tata ruang. Sedangkan menurut Pasal 1 angka 16 PP PPR mengatur bahwa peraturan zonasi adalah ketentuan yang mengatur tentang persyaratan pemanfaatan ruang dan ketentuan pengendaliannya disusun untuk setiap blok/zona peruntukan yang penetapan zonanya dalam rencana rinci tata ruang. Tujuan daripada peraturan zonasi adalah agar pemanfaatan ruang dapat dilakukan sesuai dengan rencana umum tata ruang dan rencana rinci tata ruang. Dengan diikutinya peraturan zonasi, maka akan terjadinya ketertiban pembangunan yang berwawasan lingkungan dan pemberdayaan. Selaras daripada zonasi merupakan bagian daripada pengendalian pemanfaatan ruang, maka zonasi merupakan upaya untuk mewujudkan tertib tata ruang. Hubungan daripada zonasi dan pengendalian pemanfaatan ruang sangat erat. Hal ini disebabkan karena zonasi merupakan salah satu instrument pengendalian pemanfaatan ruang. Hal ini secara jelas dinyatakan dalam Pasal 35 UUPR yaitu "Pengendalian pemanfaatan ruang dilakukan melalui penetapan peraturan zonasi, perizinan, pemberian insentif dan disentif, serta pengenaan sanksi". Sehingga dari bunyi pasal tersebut saja dapat disimpulkan bahwa zonasi memiliki hubungan yang erat dengan pengendalian pemanfaatan ruang dikarenakan zonasi adalah bagian daripada pengendalian pemanfaatan ruang.

Selanjutnya, Indonesia telah menjalani proses simulasi demokratisasi dan desentralisasi sejak akhir era Suharto dengan reformasi pada tahun 1998. Dengan pemilu baru-baru ini pada tahun 2014, Indonesia memiliki rekor dunia dalam demokrasi dengan memiliki mandat langsung terbesar dalam pemilihan presiden. Harus diakui bahwa desentralisasi membawa berkah bagi Indonesia. Melalui desentralisasi, generasi baru pemimpin lokal yang kompeten di Indonesia telah lahir. Ini jelas salah satu kisah sukses tentang bagaimana demokrasi dan desentralisasi di Indonesia telah melahirkan presiden ketujuh negara ini. Kekuatan utama 
presiden adalah kemauan dan kemampuannya untuk mengatasi salah satu masalah dalam Rule of Law dengan mendengarkan suara bisnis dan warga negara dalam pengambilan keputusan.

Visi Indonesia 2045 atau Wawasan Indonesia 2045 adalah sebuah gagasan ideal bagi Indonesia untuk menjadi negara berdaulat, maju adil dan makmur pada dirgahayu keseratus yang jatuh pada tahun 2045. Tujuan tersebut direncanakan pada 2045, karena Indonesia akan memperpingati dirgahayu 100 tahun kemerdekaannya. Visi tersebut dirumuskan oleh Kementerian Perencanaan Pembangunan Nasional Indonesia dan diluncurkan oleh Presiden Indonesia ke-7 Joko Widodo pada 9 Mei 2019. Presiden merasa optimis bahwa Indonesia akan menjadi ekonomi terbesar keempat atau kelima di dunia pada 2045.

Akibat kovergensi masalah globalisasi, revolusi industri 4.0, bonus demografi dalam persiapan sdm yang siap membangun negara, dan solusi bencana nasional (covid-19), timbul tantangan yang harus dijawab dengan pasti beberapa hal berikut, seperti, bagaimana pencapaian 5 (lima) tahun ke depan yang harus dilakukan oleh Indonesia: Pertama, pengembangan Sumber Daya Manusia (SDM) akan menjadi prioritas utama Indonesia, membangun sumber daya manusia pekerja keras, dinamis, terampil, berpengetahuan luas, teknologi dan mengundang bakat global untuk membangun Indonesia. Dan bahkan saat itu tidak dapat dicapai dengan metode lama, cara-cara baru harus dikembangkan. Kami membutuhkan dana abadi yang besar untuk manajemen SDM. Kolaborasi dengan industri juga penting untuk dioptimalkan. Dan juga penggunaan teknologi yang membuatnya mudah menjangkau semua penjuru negeri; Kedua, Terus mengembangkan infrastruktur. Infrastruktur yang menghubungkan area produksi dengan area distribusi, yang memfasilitasi akses ke area wisata, yang meningkatkan lapangan kerja baru, yang mempercepat nilai tambah ekonomi rakyat; Ketiga, Sederhanakan segala bentuk kendala peraturan, kurangi atau bahkan potong. Pemerintah harus mengundang Dewan Perwakilan Rakyat untuk mengeluarkan 2 (dua) undang-undang utama. Pertama, UU Hak Cipta Ketenagakerjaan. Kedua, UU Pemberdayaan Usaha Mikro, Kecil dan Menengah (UMKM). Masing-masing undang-undang ini akan menjadi undang-undang Omnibus, yang merupakan undang-undang yang juga merevisi beberapa undang-undang, bahkan puluhan undang-undang. Lusinan Undang-undang yang menghambat penciptaan lapangan kerja segera direvisi sekaligus. Lusinan UU yang menghambat pengembangan UMKM juga akan langsung direvisi; Keempat, Terus melakukan penyederhanaan besar-besaran birokrasi. Investasi dalam penciptaan lapangan kerja harus diprioritaskan. Prosedur yang panjang harus dipotong. Potong birokrasi yang panjang. Eselonisasi harus disederhanakan. Eselon I, eselon II, eselon III, eselon IV disederhanakan menjadi hanya 2 level, digantikan oleh jabatan fungsional yang menghargai keahlian, menghargai kompetensi. Dan melibatkan para menteri, pejabat, dan birokrat untuk secara serius menjamin pencapaian tujuan program pembangunan. Bagi mereka yang tidak serius, seperti jasnji presiden bahwa presiden akan memastikan untuk menanganinya secara langsung; dan yang terakhir, Kelima, adalah transformasi ekonomi. Transformasi dari ketergantungan pada sumber daya alam menjadi daya saing manufaktur dan layanan modern yang memiliki nilai tambah tinggi bagi kemakmuran bangsa untuk keadilan sosial bagi semua rakyat Indonesia.

Bagaimana mewujudkan harapan besar bahwa pilihan tim kerja presiden dapat melaksanakan 7 (tujuh) perintah Presiden, dengan hati nurani rakyat, yang digambarkan sebagai berikut: (1) Jangan Korup, buat sistem yang menutup kesenjangan korupsi; (2) Tidak ada visi dan misi Menteri terselubung, hanya visi dan misi Presiden dan Wakil Presiden; (3) Kerja cepat, kerja keras, kerja produktif; (4) Tidak terjebak dalam rutinitas monoton; (5) Berorientasi hasil kerja. Pekerjaan tidak hanya untuk menjamin pengiriman, tetapi dikirimkan; 
Nommensen Journal of Legal Opinion (NJLO)

Jurnal Magister Hukum Program Pascasarjana Universitas HKBP Nommensen

Volume or Nomor o1 Juli 2020 Halaman. 38-52

e-ISSN: 2723-164X p-ISSN: 2722-9858

http://ejournal.uhn.ac.id/index.php/opinion

(6) Selalu periksa masalah di lapangan dan temukan solusinya; (7) Semuanya harus serius di tempat kerja.

Bagaimana pengelolaan dan pemanfaatan Sumber Daya Alam Indonesia dijalankan sesuai Pasal 33 ayat 2, dimana diketahui bahwa lokasi geografis Indonesia yang strategis dengan luas sekitar 1.919.440 $\mathrm{km}^{2}$ menunjukkan sungguh kaya Indonesia akan sumber daya alamnya dengan semua flora, fauna, dan potensi hidrografinya serta cadangan sumber daya alamnya yang melimpah. Sumber daya alam Indonesia termasuk pertanian, kehutanan, kelautan dan perikanan, peternakan, perkebunan dan pertambangan dan sektor energi. Indonesia memiliki sumber daya alam yang melimpah sehingga harus mampu menjadikan negara Indonesia sebagai negara super power. Bagaimana Pengelolaan, pemanfaatan, pengendalian, pemeliharaan, pengawasan dan penegakan hukum Indonesia yang bersifat clean and clear sebagai negara kepulauan terbesar, tidak lazim bagi agenda kelautan untuk berubah dari sumber kebijakan utama. Warisan era Presiden Soeharto yang memusatkan kegiatan ekonomi di Pulau Jawa meninggalkan konektivitas kemaritiman Indonesia antara pulau-pulau yang tertinggal. Konektivitas darat dalam suatu pulau sering diprioritaskan melalui konektivitas berbasis laut. Banyak pulau telah berubah menjadi ekonomi subsistem, tetapi tetap terisolasi dari proses ekonomi nasional, situasi yang biasa ditemukan di pulau-pulau di Indonesia timur. Akibatnya, pembangunan daerah sering tidak seimbang dengan sebagian besar pulau di bagian timur seperti Maluku dan Papua yang menderita infrastruktur yang belum sempurna. Kesenjangan harga terjadi sebagai konsekuensi yang tak terhindarkan, dengan harga barang-barang pokok bervariasi antara wilayah barat dan timur.

Bagaimana Indonesia mengambil tantangan menjadi peluang dalam Revolusi industri 4.o untuk maju diakui oleh dunia dengan perubahan yang dilakukan bersama, secara sistematis, sesuai dengan arahan Presiden. Ada ungkapan yang muncul di tengah-tengah globalisasi yaitu "Berpikir global, bertindak secara lokal." Ungkapannya sederhana namun kaya makna. Ketika terkait dengan globalisasi, ungkapan ini memiliki arti orang yang berpikir secara global tetapi tidak melupakan budaya atau nilai-nilai asli. Tujuan dari ungkapan ini adalah untuk menciptakan sumber daya manusia yang kompeten yang tidak meninggalkan nilai-nilai leluhur bangsa. Indonesia menganut prinsip kebersamaan, prinsip gotong royong, prinsip kekeluargaan yang telah mengubah wajahnya menuju prinsip individualisme, prinsip liberalisme dan prinsip kapitalisme. Apa solusi yang dapat dilakukan pemerintah.

Bagaimana konsep pembangunan berkelanjutan (SDGs) atas partisipasi pemangku kepentingan dapat menjadi kata kunci untuk proses perubahan. Partisipasi adalah koreksi total dari berbagai sistem interaksi, termasuk interaksi antara pemerintah dengan pemerintah dan / atau pemerintah kepada rakyat. Dan perubahan antara guru dan siswa dalam sistem pendidikan. Sistem pendidikan satu arah / dogma / monolit / proses otoriter adalah waktu untuk meninggalkan dan menumbuhkan sistem pendidikan partisipatif berdasarkan pada pandangan bahwa setiap orang pada dasarnya memiliki pengalaman yang kaya untuk diproses menjadi bahan pembelajaran untuk orang lain. Mengubah paradigma tentu bukan hal yang mudah. Masalah ini tentu membutuhkan waktu dan sumber daya manusia yang siap berubah. Butuh langkah sistematis, komitmen massa dan dilakukan terus menerus. Mengapa demikian, karena masalah paradigma melibatkan masalah kehidupan dan budaya / kebiasaan / kepercayaan. Bagaimana pemerintah menyikapinya.

Bagaimana mengatasi masalah kota-kota yang pada saat ini menghadapi tantangan yang semakin besar dalam mengintegrasikan konservasi lingkungan dengan perencanaan kota. Dimana pembangunan ekonomi seringkali mengorbankan lingkungan bagi banyak kota, yang menyoroti kebutuhan mendesak untuk menyeimbangkan kedua tujuan. Dengan demikian, kerangka kota yang layak huni mencakup tiga sub lingkungan berikut untuk menunjukkan 
Nommensen Journal of Legal Opinion (NJLO)

Jurnal Magister Hukum Program Pascasarjana Universitas HKBP Nommensen

Volume or Nomor o1 Juli 2020 Halaman. 38-52

e-ISSN: 2723-164X p-ISSN: 2722-9858

http://ejournal.uhn.ac.id/index.php/opinion

tingkat keramahan dan kelestarian lingkungan, yaitu (1) Polusi, (2) Penipisan Sumber Daya Alam dan (3) Prakarsa Lingkungan. Bagaimana pemerintah menyikapinya.

Bagaimana solusi yang ditawarkan untuk lingkungan dari hal-hal yang berkaitan dengan layanan sosial dan publik, sub lingkungan termasuk, (1) Medis dan Perawatan Kesehatan, (2) Pendidikan, (3) Perumahan, Sanitasi dan Transportasi, (4) Kesetaraan Penghasilan dan Beban Demografis dan (5) Keanekaragaman dan Kohesi Komunitas. Bagaimana meningkatkan kemajuan negara Indonesia atas kemampuan dan keberhasilannya dalam melaksanakan pembangunan. Pembangunan sebagai proses perubahan terencana mencakup semua aspek kehidupan masyarakat. Efektivitas dan keberhasilan pembangunan terutama ditentukan oleh dua faktor, yaitu sumber daya manusia dan pembiayaan. Di antara kedua faktor ini yang paling dominan adalah faktor manusia. Negara yang korup bukanlah negara miskin. Salah satu alasannya adalah rendahnya kualitas manusia. Kualitas-kualitas ini tidak hanya dari segi pengetahuan atau aspek intelektual moral dan kepribadian seseorang. Bagaimana sikap pemerintah.

Indonesia ibarat kue lezat yang menjadi incaran komunitas dunia tetapi tidak dihargai oleh bangsa Indonesia sendiri. Beberapa ketidak mau tahuan, seperti kebakaran hutan, penggundulan hutan, konversi spasial yang tidak terkendali, eksploitasi di darat dan/atau di laut yang memberikan dampak likuifaksi, erosi dan abrasi, penghentian rantai ekosistem, pengeksploitasian SDA yang tidak terkendalikan, sampah yang menjadi sumber penyakit dan anak bangsa yang hidup di atas sampah. Anak-anak yang diharapkan sebagai generasi penerus bangsa yang tinggal di pinggir jalan mengemis / menjadi pengemis.

Kekayaan Sumber daya alam Indonesia tidak dikelola dan dimanfaatkan dengan baik untuk kemakmuran bagi bangsa Indonesia, tetapi hanya untuk kelompok pemegang kuasa. mengakibatkan tingginya jumlah pengangguran di Indonesia yang memiliki dampak negatif, termasuk: Tingkat kesejahteraan telah menurun; Tingkat kejahatan meningkat; Kualitas hidup menurun; Produktivitas menurun; masalah kesehatan dan makanan; Meningkatkan jumlah anak jalanan, tunawisma, pengamen, dan sebagainya; Pendapatan negara menurun; Peningkatan biaya sosial dan biaya yang dikeluarkan karena kejahatan. Pengembangan sumber daya manusia yang belum dimaksimalkan karena kepentingan yang belum mampu merubah budaya korupsi, kolaborasi dan nepotisme (KKN).

Budaya pembangunan Indonesia yang gotong royong, kebersamaan dan kekeluargaan tertinggal jauh dibelakang dan bahkan beralih ke individualisme, kapitalisme, liberalisme. Kegagalan pendidikan dalam membangun sumber daya manusia yang kuat dalam Emotional Quotient, Spiritual Quotient. Pendidikan dasar di sekolah yang masih mendahului IQ daripada pengembangan EQ, SQ dan belum nampak kejelasan membangun generasi yang bermental cinta negara. Pendidikan yang dibangun sejak kecil baik di lingkungan rumah maupun anakanak di lingkungan sekolah adalah mental selalu berkompetisi dan arogansi. Bagaimana selalu menang, menjatuhkan lawan dengan segala cara. Demikian juga yang ditunjukkan oleh orang tua dalam sikap hidup sehari-hari. Demikian banyak masalah yang harus diselesaikan oleh negara dalam mencapai tujuannya.

Dampak pembodohan rakyat, budaya KKN, akibat pemerintahan selama 32 tahun masih belum pulih kembali. Kekuasaan eksekutif yang dipegang oleh presiden. Di mana tertuang dalam Pasal 4 ayat (1) UUD 1945 yang menyatakan bahwa presiden memegang kekuasaan pemerintahan menurut Undang-Undang Dasar belum dapat dijalankan secara murni dan lebih diinervensi pada kekuasaan kekuasaan partai partai politik yang ada di Indonesia. Kekuasaan legislatif untuk membuat atau membentuk undang-undang. Pada Pasal 20 ayat (1) UUD 1945 bahwa Dewan Perwakilan Rakyat (DPR) memegang kekuasaan membentuk undang-undang. DPR hanya sebagai pewarna dari pembagian kursi partai partai dan belum melakukan 
tugasnya dalam menyerap, menghimpun, menampung dan menindak-lanjuti aspirasi rakyat. Kekuasaan yudikatif merupakan kekuasaan untuk mempertahankan undang-undang. Pada kekuasaan tersebut juga belum sanggup untuk mengadili secara clean and clear setiap pelanggaran terhadap undang-undang. Kekuasaan tersebut tertuang dalam Pasal 24 ayat (2) UUD 1945. Kekuasaan kehakiman yang dilimpahkan pada sebuah Mahkamah Agung dan badan peradilan yang berada di bawahnya dalam lingkungan peradilan umum, lingkungan peradilan agama, lingkungan peradilan militer, lingkungan peradilan tata usaha negara, dan oleh sebuah Mahkamah Konstitusi masih menjadi titipan orang orang yang berkuasa. Indonesia adalah negara berdasarkan hukum (Reshsstaat) bukan pada kekuasaan belaka (Machsstaat). Tetapi dalam perjalanan politik kenegaraan masih terbalik antara das Sein dan das Sollen. Sehingga sering terdengar dari suara rakyat bawah, bahwa "Hukum Tajam Kebawah dan Tumpul Keatas.” Bentuk negara archipelago, kemajemukan bangsa, kekayaan SDA dan Bonus demografi merupakan bonus dalam menghadapai tantangan globalisasi, revolusi industri 4.0, dan bencana nasional untuk masa pemerintah Joko Widodo saat ini yang menuju pada kepentingan pembangunan politik, ekonomi dan sosial budaya secara merata.

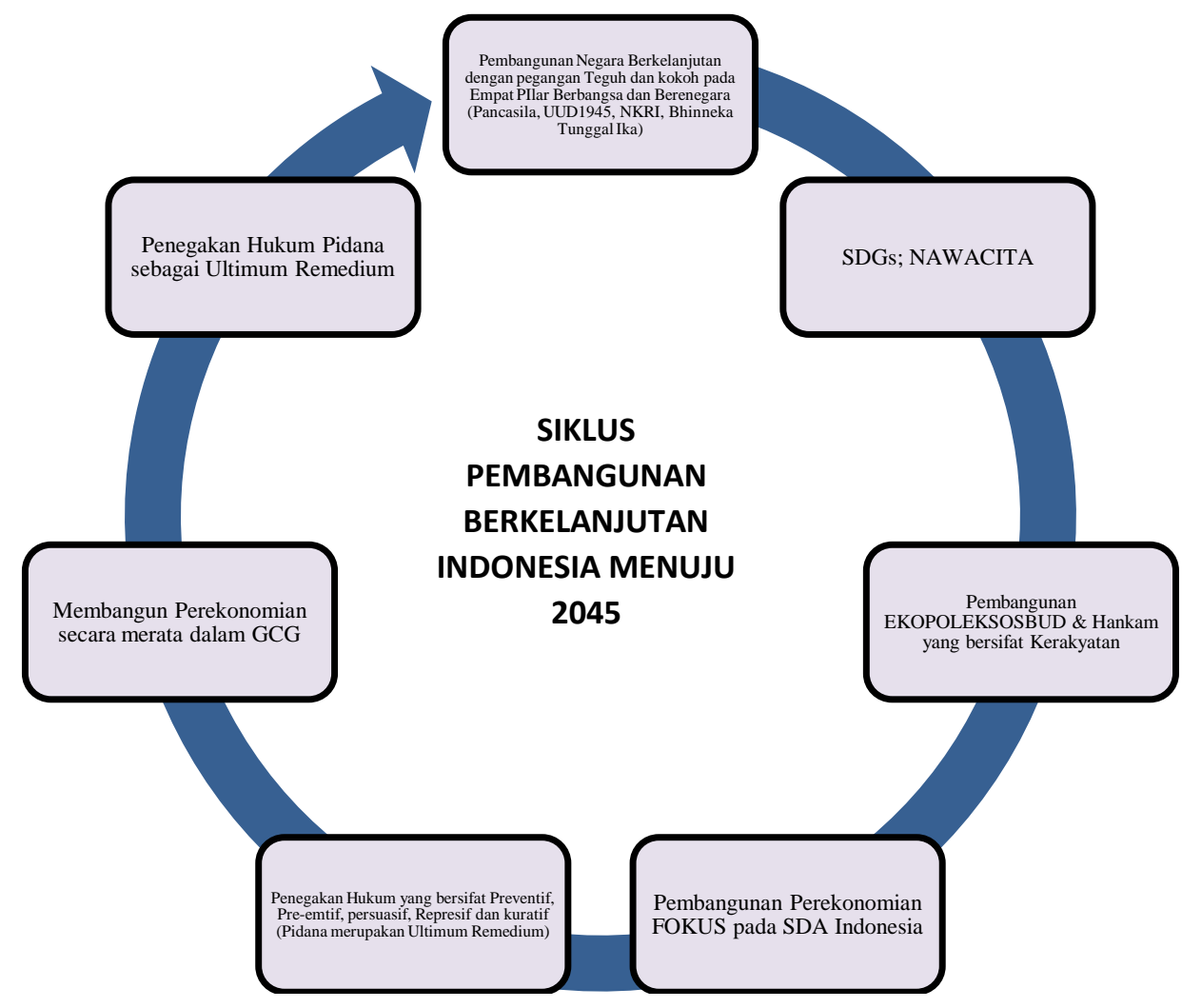

Potensi bonus demografis dalam hal populasi usia produktif jauh lebih tinggi daripada populasi usia non-produktif harus diberi perhatian khusus oleh negara dalam menerima tugas negara sebagai manusia yang mandiri kreatif dan inovatif mengembangkan pembangunan berkelanjutan sesuai SDA Indonesia. Keragaman budaya, ras, agama, dan alam di Indonesia membuat masyarakat Indonesia bangga dengan kekayaan yang dimilikinya, tetapi juga merupakan ancaman besar bagi Indonesia. Masalah politik dengan memecah belah rakyat Indonesia, melalui teroris, melalui narkoba dan banyak cara yang dilakukan oleh pihak-pihak yang tidak bertanggung jawab melalui tangan rakyat Indonesia sendiri harus disadari oleh 
bangsa Indonesia melalui edukasi edukasi dan sosialisasi pemerintah dengan cara "Lead By Example", artinya memberikan contoh yang baik oleh pemerintah.

Perlu diadakan perubahan konsep Pendidikan di Indonesia yang selama ini menciptakan perspektif yang membawa generasi ke jiwa pekerja. Sudah masanya cara memandang kedepan bukan sebagai pekerja tetapi sebagai penyedia lahan kerja. Pemerintah belum benar benar meletakkan perhatian pada dunia Pendidikan, dimana Penghasilan para pendidik masih jauh dari harapan. Apabila Para Pendidik dibekali dengan penyediaan buku-buku wajib secara gratis sesuai bidangnya dan penulisan artikel pada jurnal juga secara gratis, sepanjang untuk meningkatkan dunia Pendidikan tanpa membedakan apakah dalam bentuk Lembaga swasta atau negara. Sudah saatnya pemerintah memberikan sarana tersebut, apalagi pada masa bonus demografi. Program yang dilaksanakan antara lain inovasi dalam pengembangan Usaha Mikro, Kecil dan Menengah (UMKM) masih menghadapi tantangan pihak penguasa dalam segala alasan perizinan dan akhirnya sebagai ATM oknum tertentu. Pemerintah perlu melakukan sikap Jelas dalam kepastian hukum bagi yang menghambat perkembangan ekonomi terutama UMKM.

Belum eksplisit dibumikan pengembangan sumber daya manusia yang berjiwa Pancasilais. Masih bermunculan kelompok kelompok yang menumpang SARA dalam hidup berbangsa dan bernegara di Indonesia. Perlu tindakan tegas dalam penegakan hukum, dimana Nilai Empat Pilar Berbangsa dan Bernegara (Pancasila, UUD 1945, NKRI dan Bhinneka Tunggal Ika), telah jelas. Dapat kita pelajari negara Asia lainnya dalam penegakan hukum, tata kelola negara yang menuju pada cita-cita terbentuknya negara Indonesia. Janpatar Simamora dan Bintang ME Naibaho menyebutkan bahwa The country of Indonesia is a country of law. This is confirmed in section 1 paragraph (3) of the 1945 Constitution of the Republic of Indonesia. As a consequence of the adoption of a state of law for the Indonesian nation, all state and government activities must truly refer to existing legal rules. The emergence of ideas and thoughts of the rule of law is inseparable from the pattern of implementing state power that is vulnerable to arbitrary acts, so it is necessary to limit state power through legal instruments. Penegakan hukum dan Good and Clean Governance menjadi sesuatu yang urgensi dalam menyelesaikan kondisi Negara Indonesia yang terjepit di antara pembangunan berkelanjutan dalam tahap persatuan bangsa atas keragaman suku dan luas wilayahnya; dan sekalian memasuki tahap industrialisasi, yang dipengaruhi oleh beberapa perjanjian dengan negaranegara maju, terutama mengenai hak asasi manusia, pembatasan dalam perekonomian; dan Indonesia juga telah memasuki tahap welfarestate yang hanya dirasakan oleh para koruptor, pemegang kekuasaan, para eksekutif, legislative dan yudikatif, para elit politik. Mereka yang berkonspirasi dalam menipiskan sumber daya alam dan menebalkan kantong.

Kondisi Ketidak-berdayaan karena sudah menggurita kekuasaan dan adanya unsur pembiaran dari dunia Akademisi, Rakyat, Bangsa yang cinta negara dalam memerangi pengembangan kebijakan yang tidak selaras dengan unsur Moral tujuan pembangunan berkelanjutan negara Indonesia. Pembiaran terhadap budaya "tak tahu malu," dalam kehidupan berpolitik di Indonesia, terutama ditunjukkan oleh para koruptor yang secara sukarela melayani kembali dalam pemerintahan. Kebenaran Kata-kata Presiden Pertama Indonesia, tentang "Lebih sulit untuk berjuang melawan bangsanya sendiri ..."

\section{D.Kesimpulan}

Indonesia adalah negara agraris tetapi hari ini, Indonesia kehilangan generasi penerus yang berminat melakukan pertanian. Slogan Marsipature Hutanabe (bahasa Tapanuli) pernah hits dan sangat tenar di Sumatera Utara (Sumut) pada era Gubernur Alm. Raja Inal Siregar. Marsipature Hutanabe (Martabe) memiliki arti, 'Mari Benahi Kampung Masing- 
Nommensen Journal of Legal Opinion (NJLO)

Jurnal Magister Hukum Program Pascasarjana Universitas HKBP Nommensen

Volume or Nomor o1 Juli 2020 Halaman. 38-52

e-ISSN: 2723-164X p-ISSN: 2722-9858

http://ejournal.uhn.ac.id/index.php/opinion

masing' atau bisa diartikan perluasan dari makna Ayo Pulang ke Desa dan Mari Membangun Desa'. Pembangunan dan Pendidikan harus menuju pada slogan tersebut, apalagi saat ini Pak Joko Widodo telah melakukan pembangunan dari pinggiran.

Perluasan konsep hukum pidana baru-baru ini di Indonesia bukanlah hal yang baik dan akan menjadi masalah baru dalam pengembangan masyarakat Indonesia di masa depan. Prinsip asas kekeluargaan, kebersamaan dan gotong royong telah disalah artikan sehingga munculnya KKN. Seharusnya asas tersebut membangun rasa malu dan sadar diri dalam prilaku hidup Bersama. Perlu dikembalikan Nilai dari asas-asas tersebut melalui dunia pendidikan. Perkembangan bahasa Indonesia mengkhawatirkan, semakin banyak keluarga Indonesia menjadikan bahasa Inggris sebagai bahasa sehari-hari di rumah. Tidak hanya di rumah, penggunaan bahasa asing juga sudah mulai menjamur di sekolah. Kehadiran sekolah internasional di Indonesia, terutama di ibu kota yang menggunakan kurikulum dari luar negeri, menyebabkan sekolah menggunakan bahasa asing sebagai pengantar harian, dan anakanak tidak fasih berbahasa Indonesia. Perlu dikembalikan kesadaran nilai berbangsa melalui Pendidikan dini di sekolah-sekolah.

Menciptakan lapangan kerja dengan melibatkan semua pemangku kepentingan yang kompeten. Menegakkan hukum usia produktif wajib bekerja. Intervensi pemerintah dalam pelatihan pembukaan kesempatan kemadirian. Mengembalikan Prinsip Tujuan Negara Indonesia, membangun sifat kebersamaan antara rakyat bersama dengan pemerintah, para guru, dalam membangun negara Indonesia yang menganut 4 pilar nasionalisme: (1) Pancasila; (2) UUD 1945; (3) NKRI dan (4) Bhinneka Tunggal Ika), dan revolusi mental massal yang mengembalikan sensitivitas rasa malu. Mengembalikan budaya Indonesia yaitu, kekeluargaan, kebersamaan dan gotong royong. Kelola dan lindungi sumber daya alam Indonesia yang tersedia dengan bijak. Mengelola Manajemen Indonesia dengan mengundang para ahli dari luar negeri untuk berpartisipasi dalam mengembangkan Indonesia dengan cara yang efisien dan efektif. Jangan pernah belajar dari pengalaman Anda sendiri tetapi minta orang-orang sukses untuk melakukannya dan kemudian memilikinya.

Karena Indonesia adalah negara pariwisata, pemerintah harus mendorong untuk membangun lebih banyak lembaga bahasa. Bangun bangsa yang kuat di level sumber daya manusia yang memiliki: 1st Emotional Quotient, diikuti oleh quotients lain, seperti, Spiritual Quotient, Intelligence Quotient, Physic Quotient, Money Quotient, Money Quotient, Adverse Quotient. Pola pikir generasi tentang pembangunan berkelanjutan dengan membuat konsep ${ }_{3} \mathrm{P}$ : Orang / Sosial, Planet / Lingkungan dan Keuntungan / Ekonomi. Politik, Ekonomi dan Penegakan Hukum adalah tiga komponen penting yang harus dikelola secara Bersama dalam pemerintahan yang baik dan bersih. Mengembalikan Indonesia yang berbudaya bangga dengan keberadaan sebagai bangsa Indonesia dan produk-produk Indonesia. Kembalikan Hukum Adat dalam membantu hukum positif, terutama dalam penyelesaian rasa malu masing masing suku, perkembangan mental, moral lebih sebagai solusi. Membangun negara dimulai dari individu, keluarga, masyarakat.

\section{Daftar Pustaka}

Anju Dwivedi (2004), Metologi Pelatihan Partisipatif, Jogyakarta: Pustaka Jogja Mandiri. Amsal Bakhtiar (2004), Filsafat Ilmu, Jakarta: PT RajaGrafindo Persada.

Chew Soon Beng (2017), Labour Economics and Public Policy, New Jersey: World Scientific Co. Pte. Ltd.

Daod Joesoef, Pontjo Sutowo (2017), Nilai Keindonesiaan, Jakarta: PT Kompas Media Nusantara. 
Jurnal Magister Hukum Program Pascasarjana Universitas HKBP Nommensen

Volume o1 Nomor o1 Juli 2020 Halaman. 38-52

e-ISSN: 2723-164X p-ISSN: 2722-9858

http://ejournal.uhn.ac.id/index.php/opinion

Donghyun Park (2019), Capitalism in $21^{\text {st }}$ Century, London: World Scientific Publishing Co. Pte.Ltd.

Hamry Gusman Zakaria (2017), 5 PILAR REVOLUSI MENTAL UNTUK APARATUR NEGARA, Jakarta: PT Elex Media Komputindo.

Klaus Schwab (2017). The Fourth Industrial Revolution, Great Britain: Portfolio.

Martono Anggusti (2019), Pengelolaan Perusahaan E Kesejahteraan Tenaga Kerja, Jakarta: Bhuana Ilmu Populer.

Marsudi Wahyu Kisworo (2016), REVOLUSI MENGAJAR, Jakarta: Asik Generation.

Michael Armstrong (2006). Human Resouce Management Practice $10^{\text {th }}$ Edition, London: Kogan Page Limited.

R.Saddam Al Jihad (2018), PANCASILA IDEOLOGI DUNIA, Ciputat Tanggerang Selatan: PT. Pustaka Alvabet.

Tan Khee Giap et al (2017), 2015 Agricultural Productivity, Decentralisation, and Competitiveness Analysis for Provinces and Regions of Indonesia, London: World Scientific Publishing Co. Pte.Ltd.

Tjahjo Kumolo dan Tim (2017). Nawa Cita untuk Kesejahteraan Rakyat Indonesia, Jakarta: PT. Kompas Media Nusantara.

Yang Yue, Li Fujian (2019), The Belt and Road Initiative ASEAN Countries Perspectives, London: World Scientific Publishing Co. Pte.Ltd.

Asia Competition Institute _ World Scientific Series 2015 AGRICULTURAL PRODUCTIVITY, DECENTRALISATION, AND COMPETITIVENESS ANALYSIS FOR PROVINCES AND REGIONS OF INDONESIA.

Simamora, Janpatar dan Naibaho, Bintang ME, Statutory of The Republic of Indonesia Witness As a Government Institution Implementing Country's Power in The Indonesian State Concerns System, Proceedings of the First Nommensen International Conference on Creativity \& Technology, NICCT, 20-21 September 2019, Medan, North Sumatera, Indonesia.

Penerapan Prinsip-Prinsip Good Corporate Governance di Lingkungan BUMN, disampaikan dalam Rapat Koordinasi BUMN 17-18n April 2002 Hotel Incitation APA Indonesia Jakarta.

Undang-Undang No. 11 Tahun 2009 Tentang Kesejahteraan Sosial.

http://fwatcher.fwi.or.id/indonesia-kaya-akan-sumber-daya-alam-namun-miskin-sumberdaya-manusia/, di akses tgl. 9/11/2019

https://www.kompasiana.com/haritsah b/550f46f3813311bb2dbc65bb/think-globally-and-actlocally, di askses tgl. 9/11/2019.

http://ksp.go.id/pembangunan-berkelanjutan-sejalan-dengan-visi-nawacita/, diakses tgl. 15/11/2019.

Htps://nasional.tempo.co/read/1239173/pemerintah-berhasil-lampaui-target-penciptaanlapangan-kerja/

UMKM Outlook 2017, http://fokus-umkm.com/umkm-outlook-2017/.

Detik, Di ASEAN, Persentase Jumlah Pengusaha di RI Kalah dari Malaysia dan Thailand, https://finance.detik.com/berita-ekonomi-bisnis/2854139/di-asean-persentase-jumlahpengusaha-di-ri-kalah-dari-malaysia-dan -thailand.

Jimly Asshiddiqie, Konsolidasi Naskah UUD 1945 Setelah Perubahan Keempat, (Jakarta: PSHTN FHUI, 2002), hlm.56)

https://www.sdg203oindonesia.org/page/1-tujuan-sdg, diakses tgl.4/7/2020

https://mahawihardana.wordpress.com/2017/03/o1/zonasi-dalam-perspektif-hukum-tataruang-indonesia/, diakses tgl. 4/7/2020 
Nommensen Journal of Legal Opinion (NJLO)

Jurnal Magister Hukum Program Pascasarjana Universitas HKBP Nommensen

Volume or Nomor o1 Juli 2020 Halaman. 38-52 e-ISSN: 2723-164X p-ISSN: 2722-9858

http://ejournal.uhn.ac.id/index.php/opinion

https://www.google.com.sg/search?safe=strict\&client=safari\&channel=iphone bm\&source=hp \&ei=gJoAX OFKI 59QOJnrboCA\&q=jumlah+pulau+dan+suku+di+indonesia\&oq=jumlah \pm pulau+dan\&gs lcp=CgZwc3ktYWIQAxgAMgIIADICCAAyAggAMgIIADICCAAyAggAMg YIABAWEB4yBggAEBYQHjIGCAAQFhAeMgYIABAWEB46BQgAEIMBOgUIABCXAiCvG

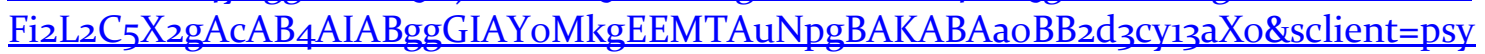
$\underline{-a b}$, diakses tgl.4/7/2020

https://www.kompasiana.com/almukhollissiagian/5d19ca2aog7f362c6624ccf2/tata-kelolapemerintahan-yang-baik-good-governance-dalam-pembangunan-berkelanjutan-sdgs, diakses tgl.4/7/2020. 